\title{
Determination of the Level of Metallic Contamination in Irrigation Vegetables, the Soil, and the Water in Gondar City, Ethiopia
}

This article was published in the following Dove Press journal: Nutrition and Dietary Supplements

Banchamlak Tegegne Berihun ${ }^{1,2}$ Dagnachew Eyachew Amare' RP Raju'

Dessie Tibebe Ayele (D) ${ }^{3}$ Henok Dagne (iD)

'University of Gondar, College of Medicine and Health Sciences, Institute of Public Health, Department of Environmental and Occupational Health \& Safety, Gondar, Ethiopia; ${ }^{2}$ East Gojjam Zone Health Department, Debre Markos, Amhara Region, Ethiopia; ${ }^{3}$ University of Gondar, College of Natural Sciences, Department of Chemistry, Gondar, Ethiopia
Correspondence: Dagnachew Eyachew Amare

Email dagnachew.eyachew@gmail.com
Background: The sources of edible vegetables in Gondar, Ethiopia, are mainly from irrigation farms grown on the banks of polluted rivers. The aim of the current study was to determine the metallic contamination level of vegetables (Ethiopian kale, cabbage, Swiss chard, lettuce, onion, tomato, and potato), the soil they are grown in, and the water used for irrigation.

Methods: The concentrations of copper $(\mathrm{Cu})$, manganese $(\mathrm{Mn})$, zinc $(\mathrm{Zn})$, chromium $(\mathrm{Cr})$, cadmium $(\mathrm{Cd})$, nickel $(\mathrm{Ni})$, and lead $(\mathrm{Pb})$ were determined using flame atomic absorption spectrometry. A composite purposive sampling method was used to collect samples from the Keha river irrigation site of Gondar city, Ethiopia. Acid digestion was performed before the samples were analyzed. Microsoft Excel was used for descriptive statistical analysis, and ANOVA was employed to compare the mean difference.

Results: In the vegetables samples, the mean concentrations of $\mathrm{Cd}, \mathrm{Ni}$, and $\mathrm{Pb}(0.23-6.25$, $7.41-51.85$, and $0-9.52 \mathrm{mg} / \mathrm{kg}$, respectively) were found to be above the limits set by the joint $\mathrm{WHO} / \mathrm{FAO}$. Swiss chard and potato were found to contain the highest levels of $\mathrm{Pb}$, while Ethiopian kale was highly contaminated with $\mathrm{Cd}$ and $\mathrm{Cr}$. For the soil samples, the $\mathrm{Pb}$ (138.09-259.24), Ni (85.18-259.26), and Cd (4.63-20.37) mean concentrations (mg/kg) exceeded the recommended maximum limits set by the FAO. The mean concentrations (in $\mathrm{mg} / \mathrm{L})$ of $\mathrm{Cr}(0.5), \mathrm{Cd}(0.046)$, and $\mathrm{Cu}(1.80)$ in the irrigated water samples were above the limit set by US EPA (2004).

Conclusion: The vegetables were contaminated with heavy metals that could be unsafe for chronic human consumption. In particular, leafy vegetables showed higher heavy metals levels compared to non-leafy vegetables.

Keywords: heavy metal, safe limits, soil, vegetables, wastewater irrigation

\section{Introduction}

Environmental pollution is posing significant public health risks worldwide, becoming a major concern in developing countries because of rapid economic activities and poor waste management. It is challenging to establish an association between environmental pollution and health effects because of the nature of pathways to exposure, limited data availability and the absence of a monitoring system. Furthermore, associations between environmental pollution and health are difficult due to the occurrence of multiple exposures, and the latency period of effect. ${ }^{1-4}$ Smith et $\mathrm{al}^{5}$ estimated that about $25-$ $30 \%$ of the total burden of disease in the world is related to environmental factors, including chemical toxicants. For example, Goyer ${ }^{6}$ reported that lead is believed to be 
responsible for $3 \%$ of cerebrovascular disease burden worldwide. It has been reported that the prevalence level of lead in the blood of children worldwide is estimated at $40 \%$, where the risk is more concerning in developing countries. ${ }^{7}$ In 2011 , arsenic-contaminated water was responsible for 9,100 deaths and 125,000 disabilities in Asia. ${ }^{6,8}$ Epidemiological studies have established an association between exposure to heavy metals and the incidence of cancer. ${ }^{9-12}$ Toxic heavy metals such as lead $(\mathrm{Pb})$, cadmium (Cd), arsenic (As), and chromium $(\mathrm{Cr})$ have the potential to bioaccumulate and interfere with biologically essential micronutrients such as zinc ( $\mathrm{Zn})$, cobalt (Co), and manganese (Mn) ${ }^{13}$ For example, dietary exposure to $\mathrm{Pb}$ and $\mathrm{Cd}$ can seriously deplete the level of iron (Fe), vitamin $\mathrm{C}$, and other essential nutrients in biological systems, leading to a reduced immunological defense, retardation of intra-uterine growth, and neurobehavioral disorders. ${ }^{9,13}$ Essential heavy metals are required biologically in trace amounts. Otherwise, if they exceed the level, they become toxic. Heavy metals, specifically lead, mercury, cadmium, arsenic, and chromium, are well known for causing birth defects. They can easily cross the placenta and deposit in a growing fetus. ${ }^{9,11}$

Even if the concentrations in the irrigation water or soil could be low, consumption of vegetables may lead to an uptake of a trace amount of heavy metals, contributing to the buildup of these toxicants in the body, bone, and other tissues, and ultimately may result in a detrimental health effect. In many developing countries including Ethiopia, it is common practice to grow vegetables using rivers passing through urban centers. Rivers crossing urban areas have been reported to be contaminated with heavy metals because of urbanization and increasing anthropogenic activities. ${ }^{14-16}$ A study in Ethiopia has shown that effluent discharge from industries, households, and institutions, solid wastes, and oily wastes from garages and fuel stations are the major sources of river pollution. ${ }^{15}$ Therefore, irrigation of urban lands with this contaminated water led to the accumulation of heavy metals in the soil and vegetables and thus uptake by plants, a problem that risks human health. ${ }^{14,-17-21}$ In Gondar city, vegetables and fruits are being grown by using water from the river Keha, where it passes within the city. The river is contaminated by untreated wastewater generated by the city. Vegetables from such irrigation fields are entering into the market and thus being consumed by people. The aim of the study was to determine concentrations of heavy metals $(\mathrm{Pb}, \mathrm{Cd}, \mathrm{Cr}$, $\mathrm{Cu}, \mathrm{Zn}, \mathrm{Ni}$, and $\mathrm{Mn}$ ) in the soil, Keha river water used for irrigation, and the vegetables cultivated.

\section{Methods and Materials}

\section{Study Area and Period}

The study area was a vegetable farming site at "Mariyam sefer", kebele 18, Gondar city, Ethiopia. Gondar city has a total population of around 224,000 (Ethiopian census 2014/ 15). The study period was from January-June in 2018.

\section{Sample Digestions}

Vegetables sample digestion and analysis were performed according to previous methods. ${ }^{22,23}$ Water and soil sample digestion and analysis were based on the method of Radulescu et $\mathrm{al}^{24}$ and Tüzen, ${ }^{25}$ respectively. Digestion of the vegetable and water samples were performed using concentrated hydrochloric acid $(\mathrm{HCl})$, nitric acid $\left(\mathrm{HNO}_{3}\right)$, and perchloric acid $\left(\mathrm{HClO}_{4}\right)$ acid mixtures, while hydrofluoric acid (HF) was additionally required for soil sample digestion. To start, $1.0 \mathrm{~g}$ of the vegetable or $0.5 \mathrm{~g}$ of soil sample was weighed out into a flask and mixed with $5 \mathrm{~mL}$ of concentrated $\mathrm{HNO}_{3}$, then left to stand overnight for predigestion. On the next day, for vegetable and soil samples in the flask were heated at $100^{\circ} \mathrm{C}$ for 15 minutes, next at $150^{\circ} \mathrm{C}$ for 30 minutes, followed by exposing at $200^{\circ} \mathrm{C}$ for the next 30 minutes until boiling stops or $2-3 \mathrm{~mL}$ solution remains. After cooling, for both sample types, $5 \mathrm{~mL}$ Conc. $\mathrm{HCl}$ was added for further digestion with the same temperature and time, again after cooling $3 \mathrm{~mL} \mathrm{HClO}_{4}$ was added and the digestion continued for 30 minutes. For soil samples, $2 \mathrm{~mL}$ HF was added to decompose silicates by heating.

A $50 \mathrm{~mL}$ aliquot of well-mixed water samples was digested by adding $5 \mathrm{~mL}$ of conc. $\mathrm{HNO}_{3}$ and heated at $95^{\circ} \mathrm{C}$ until the volume reduced to $5 \mathrm{~mL}$, then cooled followed by $5 \mathrm{~mL}$ of concentrated $\mathrm{HCl}$ addition. Because of precipitation formation, $1 \mathrm{~mL}$ of $\mathrm{HClO}_{4}$ was added and heated for further decomposition. Finally, all the digested samples were filtered using Whatman no. 42 filter paper and the filtrate was stored until analysis.

The level of heavy metals in the filtrate was determined using a 210VGP model Flame Atomic Absorption Spectrophotometer (FAAS). After digestion, samples were analyzed with triplicate injections.

\section{Quality Assurance and Control Methods}

The procedure used for digesting the vegetable, soil, and water samples was checked by spiking the vegetable, soil, and water samples with standard solutions of each metal having a known concentration. 
Calibration curves were prepared to determine the concentration of the heavy metals in the sample solutions. An intermediate standard solution $(5 \mathrm{mg} / \mathrm{L})$ of the respective metals was prepared from standard solutions comprising $1,000 \mathrm{mg} / \mathrm{L}$ of each heavy metal. Working standards were prepared by serial dilution using distilled water. Analytical wavelengths, energy, and slit width were adjusted using the manual. Working standards were aspirated into the FAAS and their absorbance were recorded. Calibration curves were plotted for each of the metals using absorbance Vs concentrations (mg/L). After establishing a calibration using the standard solutions, the sample solutions were aspirated into the FAAS instrument and readings were recorded. Blank measurements were conducted.

\section{Statistical Analysis}

Microsoft Excel was used for descriptive statistical analysis, while ANOVA was used to examine the significance level of all parameters measured.

\section{Results}

\section{Concentration of Metals in Vegetables}

The mean concentrations of the metals $(\mathrm{Cr}, \mathrm{Cu}, \mathrm{Zn}, \mathrm{Ni}$, $\mathrm{Cd}$, and $\mathrm{Pb}$ ) in the investigated vegetables are given in Table 1. The observed ranges in the concentrations of metals $(\mathrm{mg} / \mathrm{kg})$ were found to be $\mathrm{Pb}(0-9.52), \mathrm{Cd}(0.23$ 6.25), Cr (5.83-13.33), Cu (1.61-11.29), Zn (19.1688.31), Ni (7.41-51.85), and Mn (0.91-76.67).

\section{Concentration of Metals in the Soil}

The $\mathrm{pH}$, conductivity and $\mathrm{T}^{0}$ of the soil were $5.9,91.2 \mathrm{Ns} /$ $\mathrm{cm}$, and $22.7^{\circ} \mathrm{C}$, respectively. The data presented in Table 2 shows the range of mean concentration of metals in the soil. For the soil samples, $\mathrm{Pb}, \mathrm{Ni}$, and $\mathrm{Cd}$ mean concentrations exceed the Recommended Maximum Level (RML) set. $^{26}$

\section{Metals Concentration in Irrigated Water}

The physical characteristics of Keha river water were $\mathrm{pH}=7.65, \quad \mathrm{EC}=0.813$, and $\mathrm{T}^{0}=23.4$. Concentrations of metals in the irrigation water samples collected from the farming site are given in Table 3.

\section{Discussion}

This study was undertaken to determine the level of heavy metals' loads in the vegetables grown in irrigated lands in Gondar City. The levels of $\mathrm{Pb}, \mathrm{Cd}, \mathrm{Cr}, \mathrm{Cu}, \mathrm{Zn}, \mathrm{Ni}$, and $\mathrm{Mn}$ were determined at the soils the vegetables were grown, in the water used for irrigation, and the vegetables, and the results were compared against the WHO/FAO joint standard values.

The mean concentrations of $\mathrm{Cr}, \mathrm{Pb}$ (except in onion), and $\mathrm{Cd}$ detected in vegetables were higher than the limit set by the WHO/FAO, while the levels of $\mathrm{Cu}, \mathrm{Mn}, \mathrm{Zn}$, and $\mathrm{Ni}$ concentrations were within the standard. ${ }^{22}$ Elevated concentrations of heavy metals, especially $\mathrm{Cr}$ and $\mathrm{Cd}$, will result in cancer risk when the daily intake exceeds the recommended value. ${ }^{27-29}$ From the vegetable samples, swiss chard and potato (both $9.52 \mathrm{mg} / \mathrm{kg}$ ) were highly contaminated by $\mathrm{Pb}$, followed by Ethiopian kale (7.14 $\mathrm{mg} / \mathrm{kg}$ ) and Tomato $(5.95 \mathrm{mg} / \mathrm{kg})$. In 2013, FAO set the maximum limit for cadmium to be $0.05,0.1$, and 0.2 in $\mathrm{mg} / \mathrm{kg}$ for fruity, tuber, and leafy vegetables, respectively while for lead it was $0.1 \mathrm{mg} / \mathrm{kg}$ for fruity and tuber vegetables, and $0.3 \mathrm{mg} / \mathrm{kg}$ for leafy vegetables. ${ }^{30}$ Leafy vegetables are found to be more likely to absorb $\mathrm{Pb}$ than fruity vegetables. This is in line with a study conducted by Gezahegn et al. ${ }^{13}$ High concentrations of $\mathrm{Pb}$ above the permissible level in leafy vegetables were reported in a study conducted in Akaki, Addis Ababa. ${ }^{31}$ Prisacaru et al ${ }^{32}$ have reported that $\mathrm{Pb}$ and $\mathrm{Cd}$ are preferentially absorbed by leafy vegetables. The accumulation of elevated levels of $\mathrm{Pb}$ in leafy vegetables in the current study might be associated with the influence of wastewater irrigation that receive effluents from garages, hospitals, and painting materials in the city.

Bioaccumulation Factors (BAF), which is the ratio of the concentration of metal in the vegetable to concentration of metal in soil, is used to show the absorption of heavy metals in the soil and vegetables. A BAF of above 1.0 shows a higher uptake of heavy metals in vegetables compared to the soil. In all vegetables, except $\mathrm{Zn}$ for Ethiopian kale, the BAF was found to be below 1.0 (data not shown) which indicated a low uptake of heavy metals by them. The high BAF of $\mathrm{Zn}$ signifies its higher mobility from soil to vegetables or bioavailability. In contrast, in the current study lead has shown the lowest transfer factor. Gupta et $\mathrm{al}^{33}$ found out that the lead transfer factor was very low compared to $\mathrm{Fe}, \mathrm{Cd}, \mathrm{Mn}$, and $\mathrm{Cr}$. Generally, the transfer of metals from soil to vegetables may depend on the soil nature, composition of the metal parent material, vegetable species, and solubility of the metals. ${ }^{23,34,35}$ When BAF is $>0.05$, it shows that the contamination is probably because of an anthropogenic source. ${ }^{21}$ Significant 
differences between mean concentrations of heavy metals in the soil and vegetable was observed (data not shown).

Consumption of these vegetable contaminated with $\mathrm{Pb}$ has public health implications, since lead and other heavy metals have a tendency to bio-accumulate in human body tissues leading to toxicological effects. Lead is a known human toxic metal that can cause kidney dysfunction and neurological damage at a low concentration in the blood level. ${ }^{36-39}$

A higher concentration (above the limit) of $\mathrm{Cd}$ was detected in Ethiopian kale $(6.25 \mathrm{mg} / \mathrm{kg}>0.2 \mathrm{mg} / \mathrm{kg}$ limit $)$ followed by potato $(6.02 \mathrm{mg} / \mathrm{kg} 0.1 \mathrm{mg} / \mathrm{kg}$ limit$)$, onion (3.93 $\mathrm{mg} / \mathrm{kg}>0.05 \mathrm{mg} / \mathrm{kg}$ limit$)$ and tomato $(1.97 \mathrm{mg} / \mathrm{kg}>0.05 \mathrm{mg} /$ $\mathrm{kg}$ limit). The Cd level found in this study was far greater than the level $(<0.2 \mathrm{mg} / \mathrm{kg})$ reported in a study conducted by Misganaw and Nardos. ${ }^{40}$ Chromium load in Ethiopian kale $(13.33 \mathrm{mg} / \mathrm{kg})$ was highest, followed by Swiss chard (11.67 $\mathrm{mg} / \mathrm{kg})$, and Cabbage (10 mg/kg). The higher concentrations for these metals were observed in leafy vegetables, which is supported by previous studies. ${ }^{41-43}$ This implies that consumption of leafy vegetables compared to root vegetables might contribute to a higher human exposure.

In the water samples, only $\mathrm{Cr}, \mathrm{Cd}$, and $\mathrm{Cu}$ were found above the limit set by the US EPA, $2004 .^{44}$ The reason that the concentration of metals in the vegetables was greater than the irrigated water could be the bioaccumulation capacity of plants. In addition, the physiology of the various plants may determine the level of accumulation of heavy metals starting from up taking in soil to a preferential storage in the plant parts such as roots and leaves. ${ }^{41,45,46}$ A pH level of soil can determine the mobility and uptake of heavy metals by plants. ${ }^{40}$ The current study showed that toxicological important heavy metals $(\mathrm{Pb}, \mathrm{Cr}$, and $\mathrm{Cd}$ ) were in higher quantity in leafy vegetables compared to the rest of studied heavy metals, which are less toxic.

The mean concentrations of $\mathrm{Cr}, \mathrm{Cd}$, and $\mathrm{Cu}$ in irrigated water were above the limit set by the US EPA (2004). This shows that the continuous use of sewage and wastewater for agricultural land can increase the burden of heavy metals on the soil. ${ }^{47}$ For most of the metals, as shown in Table 3, the concentration of metals was decreasing from the river water to the water reached in the farm where vegetables were grown. This could be because of the natural deposition of metals when the water flows slowly along the irrigation channel.

The highest and lowest $\mathrm{Pb}$ were observed in cabbage soil (295.24 mg/kg) and Ethiopian kale soil (138.09 mg/kg),

Table I Mean Concentration of Metals (in $\mathrm{mg} / \mathrm{kg}$ ) in Vegetables

\begin{tabular}{|c|c|c|c|c|c|c|c|}
\hline \multirow[t]{2}{*}{ Vegetables } & \multicolumn{7}{|c|}{ Metals (Mean \pm SD) } \\
\hline & $\mathbf{P b}$ & Cd & $\mathrm{Cr}$ & $\mathrm{Cu}$ & $\mathbf{Z n}$ & $\mathbf{N i}$ & Mn \\
\hline Cabbage & $3.80 \pm 3.66$ & $1.62 \pm 1.29$ & $10 \pm 3.16$ & $2.82 \pm 0.67$ & $27.87 \pm 4.4 I$ & $7.41 \pm 4.54$ & $7.27 \pm 3.54$ \\
\hline Swiss chard & $9.52 \pm 4.12$ & $1.38 \pm 1.20$ & II. $.66 \pm 5.77$ & $1.88 \pm 1.23$ & $48.65 \pm 8.33$ & $51.85 \pm 25.6$ & $76.66 \pm 5.25$ \\
\hline Ethiopian kale & $7.14 \pm 0$ & $6.25 \pm 1.20$ & $13.33 \pm 2.88$ & $2.4 I \pm 0.80$ & $88.3 \pm 6.145$ & $11.11 \pm 5.55$ & $30.61 \pm 2.62$ \\
\hline Tomato & $5.95 \pm 2.91$ & $2.43 \pm 0.85$ & $5.8 \pm 3.76$ & $2.01 \pm 1.11$ & $24.6 I \pm 0.79$ & $13.88 \pm 7.65$ & $2.42 \pm 1.37$ \\
\hline Potato & $9.52 \pm 4.12$ & $6.01 \pm 0.80$ & $6.66 \pm 2.88$ & $11.29 \pm 0$ & $56.70 \pm 8.34$ & $20.37 \pm 3.2$ & $0.91 \pm 0.91$ \\
\hline Onion & $0 \pm 0$ & $3.93 \pm 1.06$ & $6.66 \pm 2.88$ & $2.15 \pm 1.67$ & $19.15 \pm 9.12$ & $9.25 \pm 6.41$ & $3.94 \pm 2.28$ \\
\hline Lettuce & $2.38 \pm 4.12$ & $0.23 \pm 0.40$ & $6.66 \pm 2.88$ & $1.61 \pm 1.39$ & $64.55 \pm 6.46$ & $48.14 \pm 3.21$ & $41.52 \pm 1.89$ \\
\hline
\end{tabular}

Table 2 Metals Mean Concentration in Soil (mg/kg)

\begin{tabular}{|l|l|l|l|l|l|l|l|}
\hline \multirow{2}{*}{ Soil } & \multicolumn{2}{l}{ Metals (Mean士SD) } \\
\cline { 2 - 8 } & $\mathbf{P b}$ & $\mathbf{C d}$ & $\mathbf{C r}$ & $\mathbf{C u}$ & $\mathbf{Z n}$ & $\mathbf{N i}$ & $\mathbf{M n}$ \\
\hline Cabbage & $295.2 \pm 75.9$ & $9.027 \pm 1.70$ & $48.33 \pm 9.83$ & $119.89 \pm 19.55$ & $250.19 \pm 38$ & $203.7 \pm 50$ & $851.8 \pm 88.06$ \\
Swiss chard & $242.85 \pm 0$ & $4.62 \pm 2.12$ & $40 \pm 10$ & $104.83 \pm 5.81$ & $191.95 \pm 12$ & $188.9 \pm 50.9$ & $730.30 \pm 3.78$ \\
Ethiopian kale & $138.1 \pm 8.24$ & $20.37 \pm 2.12$ & $46.66 \pm 5.77$ & $138.7 \pm 8.98$ & $55.93 \pm 17.8$ & $259.25 \pm 17$ & $932.72 \pm 183$ \\
Tomato & $154.76 \pm 16$ & $12 \pm 1.89$ & $36.66 \pm 8.16$ & $66.9 \pm 1.16$ & $197.3 \pm 14.6$ & $140.74 \pm 24$ & $734.54 \pm 29.5$ \\
Potato & $180.95 \pm 21.8$ & $8.79 \pm 1.60$ & $33.33 \pm 5.77$ & $28.06 \pm 39.95$ & $194.63 \pm 30$ & $122.2 \pm 50.9$ & $676.36 \pm 57.7$ \\
Onion & $176.2 \pm 29.73$ & $14.35 \pm 2.12$ & $33.33 \pm 5.77$ & $87.09 \pm 19.35$ & $246.36 \pm 53$ & $140.74 \pm 16$ & $869.69 \pm 23$ \\
Lettuce & $171.4 \pm 28.5$ & $8.79 \pm 1.60$ & $30 \pm 0$ & $82.79 \pm 17.69$ & $270.5 \pm 24.9$ & $85.18 \pm 32$ & $815.2 \pm 117$ \\
\hline
\end{tabular}


Table 3 Mean Concentrations of Metals in Irrigation Water $(\mathrm{mg} / \mathrm{L})$

\begin{tabular}{|c|c|c|c|c|c|c|c|}
\hline \multirow[t]{2}{*}{ Water } & \multicolumn{7}{|c|}{ Metals (Mean \pm SD) } \\
\hline & $\mathbf{P b}$ & $\mathrm{Cr}$ & Cd & $\mathrm{Cu}$ & $\mathbf{N i}$ & Mn & $\mathbf{Z n}$ \\
\hline Keha (outside the field) & $0.26 \pm 0.21$ & $0.5 \pm 0.54$ & $0.046 \pm 0.01$ & $1.80 \pm 0.14$ & $0.17 \pm 0.15$ & $0.478 \pm 0.16$ & $0.86 \pm 0.01$ \\
\hline Within the field & $0.09 \pm 0.15$ & $1.33 \pm 1.03$ & $0.043 \pm 0.01$ & $0.01 \pm 0.01$ & $0.11 \pm 0.14$ & $0.46 \pm 0.049$ & $0.86 \pm 0.006$ \\
\hline Before entering the field & $0.214 \pm 0.2$ & $I \pm 0.63$ & $0.035 \pm 0.02$ & $0.019 \pm 0.02$ & $0.076 \pm 0.09$ & $0.43 \pm 0.048$ & $0.868 \pm 0.01$ \\
\hline EPA MRL (2004) & 5 & 0.1 & 0.01 & 0.2 & 0.2 & 0.2 & 2 \\
\hline
\end{tabular}

respectively. Cd was highest in the soil of Ethiopian kale $(20.37 \mathrm{mg} / \mathrm{kg}$ ) and lowest in Swiss chards soil $(4.63 \mathrm{mg} / \mathrm{kg})$. The highest concentration of $\mathrm{Cr}$ was observed from the cabbage soil $(48.33 \mathrm{mg} / \mathrm{kg})$ while the lettuce soil was found to contain the lowest $(30 \mathrm{mg} / \mathrm{kg})$. The highest concentration of $\mathrm{Cu}$ was observed in Ethiopian kale soil $(138.71 \mathrm{mg} / \mathrm{kg})$ followed by potato soil $(28.06 \mathrm{mg} / \mathrm{kg})$. Lettuce soil was found to hold the highest $\mathrm{Zn}$ content $(270.5 \mathrm{mg} / \mathrm{kg})$, whilst Ethiopian kale soil possessed the lowest $(55.94 \mathrm{mg} / \mathrm{kg}) \mathrm{Zn}$ concentration. The Ethiopian kale soil $(259.26 \mathrm{mg} / \mathrm{kg})$ and Lettuce soil $(85.18 \mathrm{mg} / \mathrm{kg})$ were found containing the highest and lowest $\mathrm{Ni}$ concentrations, respectively. The current results showed that soils in which vegetables were grown are contaminated by metals. Therefore, the exceeded value found in the vegetable parts is likely the result of the contaminated soil.

In summary, from all the studied heavy metals, the concentrations of the most toxic metals, namely $\mathrm{Cr}, \mathrm{Cd}$, and $\mathrm{Pb}$, found in all of the vegetables studied were above the safe limits, whilst $\mathrm{Zn}, \mathrm{Ni}, \mathrm{Cu}$, and $\mathrm{Mn}$ were within the limit set. ${ }^{26}$ Leafy vegetables were found to contain higher heavy metals levels than roots, which implies that leafy vegetables may pose a greater risk for chronic human consumption. The reported high level of heavy metals in the vegetables and soils indicated that the irrigation water has been possibly contaminated by anthropogenic sources. The bio-accumulative nature of these heavy metals in the human body could bring a long-term health impact.

\section{Limitation of the Study}

The study was only conducted in the dry season.

\section{Data Sharing Statement}

Data will be available upon request.

\section{Ethical Consideration and Consent to Participate}

A Letter of Ethical approval was received from the Institute of Public Health ethical clearance committee. An official letter of co-operation was also obtained from Gondar city urban Agricultural office. Individual informed consent was taken from the owners and farmers of the vegetation after a brief explanation about the purpose of the study.

\section{Acknowledgments}

We would like to thank Asres Kahaliw and Yohannes Abebe at the Department of Chemistry, University of Gondar for their kind help during the experimental works.

\section{Author Contributions}

All authors contributed to data analysis, drafting, or revising the article, have agreed on the journal to which the article will be submitted, gave final approval of the version to be published, and agree to be accountable for all aspects of the work.

\section{Funding}

The study didn’t receive any specific project funds.

\section{Disclosure}

The authors declare that they do not have competing interests.

\section{References}

1. Briggs D. Environmental pollution and the global burden of disease. Br Med Bull. 2003;68(1):1-24.

2. Bradl H. Heavy Metals in the Environment: Origin, Interaction and Remediation. Elsevier; 2005.

3. Mishra S, Bharagava RN, More N, et al. Heavy metal contamination: an alarming threat to environment and human health. Environ Biotech. 2019;103-25.

4. Jia Z, Li S, Wang L. Assessment of soil heavy metals for eco-environment and human health in a rapidly urbanization area of the upper Yangtze Basin. Sci Rep. 2018;8(1):1-14.

5. Smith KR, Corvalán CF, Kjellström T. How much global ill health is attributable to environmental factors? Epidemiology. 1999;573-584.

6. Goyer R. Issue Paper on the Human Health Effects of Metals. US Environmental Protection Agency; 2004.

7. Mamtani R, Stern P, Dawood I, Cheema S. Metals and disease: A global primary health care perspective. J Toxicol. 2011;2011.

8. Järup L. Hazards of heavy metal contamination. Br Med Bull. 2003;68 (1):167-182. 
9. Agrawal A. Toxicity and fate of heavy metals with particular reference to developing foetus. Adv Life Sci. 2012;2(2):29-38.

10. Fasinu PS, Orisakwe OE. Heavy metal pollution in sub-Saharan Africa and possible implications in cancer epidemiology. Asian Pacific J Cancer Prevent. 2013;14(6):3393-3402. doi:10.7314/ APJCP.2013.14.6.3393

11. Mahurpawar M. Effects of heavy metals on human health. Int $J$ Res Granthaalayah. 2015;530:1-7.

12. Sharma A, Katnoria JK, Nagpal AK. Heavy metals in vegetables: screening health risks involved in cultivation along wastewater drain and irrigating with wastewater. SpringerPlus. 2016;5(1):1-16. doi:10.1186/s40064-016-2129-1

13. Iyengar GV, Nair PP. Global outlook on nutrition and the environment: meeting the challenges of the next millennium. Sci Total Environ. 2000;249(1-3):331-346. doi:10.1016/S0048-9697(99) 00529-X

14. Deribachew B, Amde M, Nigussie-Dechassa R, Taddese A. Selected heavy metals in some vegetables produced through wastewater irrigation and their toxicological implications in Eastern Ethiopia. African J Food Agr Nutr Dev. 2015;15(3):10013-10032.

15. Gebre G, Van Rooijen DJ. Urban water pollution and irrigated vegetable farming in Addis Ababa. 2009.

16. Hamid A, Mushtaq A, Nazir R, Asghar S. Heavy metals in soil and vegetables grown with municipal wastewater in Lahore. Bangladesh J Sci Ind Res. 2017;52(4):331-336. doi:10.3329/bjsir.v52i4.34821

17. Gezahegn WW, Srinivasulu A, Aruna B, et al. Study of heavy metals accumulation in leafy vegetables of Ethiopia. OSR $J$ Environ $S c i$. 2017;11(5):57-68.

18. Khanna P, Khanna P. Assessment of heavy metal contamination in different vegetables grown in and around urban areas. Res J Environ Toxicology. 2011;5(3):162. doi:10.3923/rjet.2011.162.179

19. Inoti KJ, Fanuel K, George O, Paul O. Assessment of heavy metal concentrations in urban grown vegetables in Thika Town, Kenya. African J Food Sci. 2012;6(3):41-46.

20. Tasrina R, Rowshon A, Mustafizur A, Rafiqul I, Ali M. Heavy metals contamination in vegetables and its growing soil. J Environ Anal Chem. 2015;2(142):2.

21. Zhou H, Yang W-T, Zhou X, et al. Accumulation of heavy metals in vegetable species planted in contaminated soils and the health risk assessment. Int $J$ Environ Res Public Health. 2016;13(3):289. doi:10.3390/ijerph13030289

22. Akan J. Determinations of Some Heavy Metals in Vegetable Samples from Biu Local Government Area, Borno State, North Eastern Nigeria. Int $J$ Environ Monitoring Analysis. 2013;1(2):40-46. doi:10.11648/j.ijema.20130102.11

23. Intawongse M, Dean JR. Uptake of heavy metals by vegetable plants grown on contaminated soil and their bioavailability in the human gastrointestinal tract. Food Addit Contam. 2006;23(1):36-48. doi:10.1080/02652030500387554

24. Radulescu C, Dulama I, Stihi C, et al. Determination of heavy metal levels in water and therapeutic mud by atomic absorption spectrometry. Romanian J Phys. 2014;1(59):1057-1066.

25. Tüzen M. Determination of heavy metals in soil, mushroom and plant samples by atomic absorption spectrometry. Microchem J. 2003;74 (3):289-297. doi:10.1016/S0026-265X(03)00035-3

26. Codex A, Intergovernmental TFO. Joint FAO/WHO Food Standard Programme Codex Alimentarius Commission Twenty-Fourth Session Geneva, 2-7 July 2001. Codex. 2001.

27. Chang CY, Yu HY, Chen J, Li F, Zhang H, Liu C. Accumulation of heavy metals in leaf vegetables from agricultural soils and associated potential health risks in the Pearl River Delta, South China. Environ Monit Assess. 2014;186(3):1547-1560. doi:10.1007/s10661-013-3472-0
28. Sá I, Semedo M, Cunha ME. Kidney cancer. Heavy Metals Biomed J. 2016;1(1):25-28.

29. Lin J, Zhang F, Lei Y. Dietary intake and urinary level of cadmium and breast cancer risk: A meta -analysis. Cancer Epidemiol. 2016;42:101-107. doi:10.1016/j.canep.2016.04.002

30. Joint F, Organization WH, Additives W. Evaluation of Certain Food additives: Eighty-Fourth Report of the Joint FAO. World Health Organization; 2017.

31. Woldetsadik D, Drechsel P, Keraita B, Itanna F, Gebrekidan H. Heavy metal accumulation and health risk assessment in wastewater-irrigated urban vegetable farming sites of Addis Ababa, Ethiopia. Int $J$ Food Contamination. 2017;4(1):9. doi:10.1186/s40550-017-0053-y

32. AE Prisacaru, LC Apostol, Ropciuc S. Estimation of heavy metal levels in green leafy vegetables purchased from Suceava. Food Environ Safety J. 2017;16:4.

33. Gupta S, Satpati S, Nayek S, Garai D. Effect of wastewater irrigation on vegetables in relation to bioaccumulation of heavy metals and biochemical changes. Environ Monit Assess. 2010;165(1-4):169177. doi:10.1007/s10661-009-0936-3

34. Kabala C, Chodak T, Szerszen L, Karczewska A, Szopka K, Fratczak U. Factors influencing the concentration of heavy metals in soils of allotment gardens in the city of Wroclaw, Poland. Fresenius Environ Bulletin. 2009;18(7):1118-1124.

35. Mench M, Vangronsveld J, Didier V, Clijsters H. Evaluation of metal mobility, plant availability and immobilization by chemical agents in a limed-silty soil. Environ Pollut. 1994;86(3):279-286. doi:10.1016/ 0269-7491(94)90168-6

36. Assi MA, Hezmee MNM. Detrimental Effects Lead Human Animal Health Veterinary World. Int $J$ Sci. 2016;9(6):660.

37. Antonio M, Leret M. Study of the neurochemical alterations produced in discrete brain areas by perinatal low-level lead exposure. Life Sci. 2000;67(6):635-642. doi:10.1016/S0024-3205(00)00655-X

38. Antonio MT, Corredor L, Leret ML. Study of the activity of several brain enzymes like markers of the neurotoxicity induced by perinatal exposure to lead and/or cadmium. Toxicol Lett. 2003;143(3):331340. doi:10.1016/S0378-4274(03)00194-2

39. Fels LM, et al. Adverse effects of chronic low level lead exposure on kidney function-a risk group study in children. Nephrology Dialysis Trans. 1998;13(9):2248-2256. doi:10.1093/ndt/13.9.2248

40. Misganaw E, Nardos T. Heavy Metal Concentration in Soil and Swiss Chard Grown in the Vicinity of Addis Ababa, Ethiopia. Toxicol Environ. 2017;1;12.

41. Singh S, Zacharias M, Kalpana S, Mishra S. Heavy metals accumulation and distribution pattern in different vegetable crops. J Environ Chem Ecotoxicology. 2012;4(4):75-81.

42. Mekonnen KN, Ambushe AA, Chandravanshi BS, Redi-Abshiro M, McCrindle RI. Assessment of potentially toxic elements in Swiss chard and sediments of Akaki River, Ethiopia. Toxicol Environ Chem. 2014;96(10):1501-1515.

43. Ali MH, Al-Qahtani KM. Assessment of some heavy metals in vegetables, cereals and fruits in Saudi Arabian markets. Egypt $J$ Aquatic Res. 2012;38(1):31-37.

44. USEPAOoWMMS D, Transfer NRMRLT, Division S. Guidelines for Water Reuse. US Environmental Protection Agency; 2004.

45. Farooq M, Anwar F, Rashid U. Appraisal of heavy metal contents in different vegetables grown in the vicinity of an industrial area. Pakistan J Botany. 2008;40(5):2099-2106.

46. Radulescu C, Stihi C, Popescu I, Dulama I, Chelarescu E, Chilian A. Heavy metal accumulation and translocation in different parts of Brassica oleracea L. Romanian J Phys. 2013;58(9-10):1337-1354.

47. Seema KA. Accumulation of heavy metals in soil and green leafy vegetables, irrigated with wastewater. J Environ Sci Toxic Food Tech. 2016;10(10):8-19. 


\section{Publish your work in this journal}

Nutrition and Dietary Supplements is an international, peerreviewed, open access journal focusing on research into nutritional requirements in health and disease, impact on metabolism and the identification and optimal use of dietary strategies and supplements necessary for normal growth and development. The journal welcomes submitted papers covering original research, basic science, clinical \& epidemiological studies, reviews and evaluations, guidelines, expert opinion and commentary, case reports and extended reports. The manuscript management system is completely online and includes a very quick and fair peer-review system, which is all easy to use. Visit http://www.dovepress.com/testimonials.php to read real quotes from published authors.

Submit your manuscript here: https:/www.dovepress.com/nutrition-and-dietary-supplements-journal 